\title{
Gambaran Pengetahuan dan Sikap Ibu Hamil Terhadap Transmisi dan \\ Pencegahan HIV/AIDS di Makassar
}

\author{
Azizah Nurdin* \\ Program Studi Pendidikan Dokter, Fakultas Kedokteran dan Ilmu Kesehatan UIN Alauddin \\ Makassar
}

\begin{abstract}
ABSTRAK
Penyebaran penyakit HIV/AIDS pada wanita hamil dapat menjadi masalah ganda dengan adanya resiko penularan pada janinnya. Keadaan ini seharusnya menjadi perhatian dengan meningkatkan langkah preventif dengan meningkatkan pengetahuan dan sikap ibu hamil mengenai HIV/AIDS yang selanjutnya akan menurunkan angka transmisinya. Penelitian ini bertujuan mengetahui gambaran tingkat pengetahuan dan sikap ibu hamil terkait cara penularan HIV/AIDS. Pada penelitian ini didapatkan beberapa temuan menarik antara lain pengetahuan yang salah bahwa penularan HIV dapat melalui melalui makanan masih tinggi (71\%) dan penularannya melalui ASI (35\%). Sikap positif ditunjukkan dengan bersedia merawat penderita HIV/AIDS (77\%) namun disayangkan sikap tidak ingin membeli makanan pada penjual dengan mengidap HIV/AIDS ditunjukkan pada $81 \%$ responden. Penelitian ini memberikan informasi penting bagi pentingnya peningkatan informasi mengenai HIV/AIDS sehingga dapat memutus mata rantai penularan pada janin serta membangun sikap positif kepada penderita HIV/AIDS.
\end{abstract}

Kata kunci : HIV/AIDS, pengetahuan, ibu hamil

\section{PENDAHULUAN}

AIDS saat ini merupakan pandemik. Pada tahun 2007, gabungan komisi AIDS intenasional mengestimasi sekitar 60 juta penduduk dunia menderita HIV/AIDS dengan 25 juta kematian serta 14 juta anak-anak menjadi yatim sejak mulainya epidemik. ${ }^{1}$

\section{Kementerian}

melaporkan bahwa angka kejadian HIV/AIDS tertinggi adalah pada umur 20$29(31,4 \%)$ dimana presentase kejadian AIDS lebih banyak pada lelaki (56\%) dengan faktor risiko yang bervariasi mulai dari heteroseksual (66\%), penasun (11\%), homoseksual (4\%) dan perinatal $(3 \%)^{2}$
Peningkatan kejadian HIV pada perempuan juga tidak terelakkan. Dari keseluruhan ibu hamil yang menderita HIV/AIDS, hanya $14 \%$ yang mendapatkan pengobatan atau profilaksis untuk pencegahan transmisi ke bayi. Selain itu, diperkirakan 3200 anak-anak terinfeksi baru HIV akibat penularan dari ibu ke anak . Kebanyakan anak terjangkit HIV/AIDS ditularkan dari ibu pada saat kehamilan, persalinan dan menyusui. ${ }^{3}$

Peningkatan HIV yang tinggi pada wanita, mengindikasikan pentingnya pencegahan transmisi HIV AIDS dari ibu ke anak. Dalam hal ini, pengetahuan ibu tentang pencegahan dan penularan HIV/AIDS sangat signifikan dalam hal 
menurunkan angka kejadian HIV pada anak. Jika ibu hamil sadar dan tahu tentang kemungkinan penularan HIV/AIDS selama hamil, maka ibu akan cenderung memeriksakan diri agar jika memang positif maka pencegahan ke bayi dapat segera dilakukan

Penyakit HIV yang terjadi pada anak adalah refleksi nyata dari infeksi HIV yang telah menjangkit perempuan, karena rute dominan transmisi HIV ke anak adalah melalui ibunya. Semakin banyak wanita muda usia reproduksi terjangkit HIV semakin tinggi pula kemungkinan banyak anak yang terjangkit HIV melalui transmisi pada saat kehamilan, persalinan dan menyusui.

Angka kejadian HIV/AIDS pada perempuan terutama ibu rumah tangga yang sedang hamil melatarbelakangi kami untuk melaksanakan penelitian ini. Melalui penelitian ini kami harapkan dapat melihat gambaran peningkatan pengetahuan dan sikap ibu hamil terhadap transmisi dan pencegahan HIV/AIDS sehingga ibu hamil yang berisiko terhadap HIV/AIDS dapat segera melakukan pemeriksaan (HIV testing) sehingga penularan ke bayi dapat diminimalkan lebih lanjut lagi, ibu hamil tersebut diharapkan dapat menjadi pionir untuk mensosialisasikan tentang transmisi HIV/AIDS dari ibu ke anak serta pencegahan HIV AIDS pada perempuan lainnya di Sulawesi Selatan.

\section{BAHAN DAN METODE}

Penelitian ini merupakan penelitian deskriptif dengan mengambil sampel pada Puskesmas Kassi-Kassi pada Tahun 2018 sebanyak 100 sampel yang memenuhi kriteria inklusi berupa ibu hamil dan bersedia menandatangi informed consent. Instrumen penelitian berupa kuisoner berisi pengetahun dan sikap mengenai pencegahan dan penularan HIV/AIDS. Data disajikan dalam bentuk gambaran proporsi dengan menggunakan analisis univariat.

\section{HASIL PENELITIAN}

Karakteristik responden penelitian yang berjumlah 100 orang yakni mayoritas ibu hamil berumur usia 21-55 tahun yakni $75 \%$, sementara ibu hamil yang hamil dengan umur berisiko yakni $25 \%$ yakni 5 $\%$ berumur $<21$ tahun sedangkan $20 \%$ lainnya berumur $>35$ tahun. Dari segi pendidikan, kita dapatkan bahwa responden mayoritas telah berpendidkan SMA atau menjalani pendidikan selama 12 tahun yakni sebanyak $57 \%$ sedangkan yang berpendidikan SD_SMP sebanyak $24 \%$ dan berpendidikan diploma/sarjana adalah $19 \%$. Ibu hamil kali ini mayoritas mengandung anak yang ketiga atau lebih sebanyak $56 \%$ sedangkan $44 \%$ lainnya mengandung anak yang ke-1 atau ke-2. 
Pada penelitian didapatkan bahwa hanya $58 \%$ persen yang menjawab benar bahwa salah satu cara mengurangi transmisi HIV adalah dengan memiliki 1 pasangan. Selain itu ternyata masih banyak miskonsepsi yang beredar di masyarakat yang meyakini bahwa HIV masih tertular lewat nyamuk yakni $65 \%$ responden. Dominan responden (69\%) wanita hamil tidak mengetahui bahwa kondom merupakan salah satu alat untuk pencegahan penularan HIV/AIDS. Selain itu, $71 \%$ responden juga masih mempercayai jika penyakit HIV menular melalui makanan. Penularan HIV dari ibu ke bayi yang merupakan rute penting selama hamil persalinan dan menyusui, ternyata juga masih belum dipahami oleh sebagian ibu hamil yang menjadi responden.

Demikian halnya dengan sikap responden terhadap orang dengan HIV/AIDS. Didapatkan dari kuesioner awal bahwa hanya $9 \%$ ibu hamil yang mau membeli makanan yang dijual oleh orang dengan HIV/AIDS, hanya $58 \%$ yang mau merahasiakan ODHA, dan hanya $35 \%$ yang membiarkan seorang ODHA yang bekerja sebagai guru untuk aktif mengajar.

\section{PEMBAHASAN}

Temuan pada penelitian ini adalah pengetahuan yang rendah (65\%) mengenai HIV/AIDS dapat menular melalui ASI ibu.
Penelitian Kluwers dkk $(2010)^{4}$ juga menemukan bahwa $48 \%$ responden mengetahui bahwa menyusui adalah salah satu rute transmisi bagi HIV/AIDS. Pengetahuan mengenai penyebaran HIV/AIDS melalui seks yang tidak aman dan darah sangat baik dengan mencapai lebih dari $90 \%$, sayangnya masih terdapat $34 \%$ responden yang mempercayai bahwa HIV/AIDS menyebar melalui sentuhan tangan.

Pengetahuan komprehensif mengenai HIV/AIDS didefinisikan sebagai (1) mengetahui bahwa penggunaan kondom secara konsisten selama hubungan seks dan memiliki satu pasangan HIV-negatif yang setia dapat mengurangi resiko terkena HIV, (2) mengetahui bahwa orang yang terlihat sehat bisa saja menderita HIV, virus yang menyebabkan AIDS dan (3) menolak dua miskonsepsi yang paling sering tentang HIV, yakni transmisi HIV melalui gigitan nyamuk dan berbagi makanan. ${ }^{3}$

Banyak faktor yang mempengaruhi pengetahuan dan sikap perempuan tentang pencegaahan dan penularan HIV/AIDS mulai dari umur, pendidikan perempuan itu sendiri, pendidikan pasangan hidup ${ }^{5}$, interaksi dengan media massa, pendapatan, tingkat pendidikan hingga seberapa sering perempuan tersebut terpapar dengan media massa atau elektronik. ${ }^{6,7}$ Edukasi dan pemberian informasi langsung secara 
verbal dari pelayanan kesehatan pada ibu hamil tentang penyebaran HIV dengan bahasa yang mudah dimengerti sangatlah penting sebab ibu yang memiliki pendidikan rendah dan ketidakmampuan untuk membaca sangatlah mempengaruhi kemampuan mereka dalam mengerti dan memahami materi edukasi dari TV, iklan maupun leaflet. ${ }^{8}$

Konseling dan edukasi sangat penting dalam meningkatkan pengetahuan dan sikap perempuan dalam pencegahan penularan HIV/AIDS dari ibu ke anak. Pada penelitian di Jember yang dilakukan pada beberapa ibu hamil menunjukkan bahwa sikap ibu hamil terhadap pencegahan dan penularan HIV/AIDS mengalami peningkatan setelah dilakukan konseling dan edukasi secara menyeluruh. Setelah mendapatkan edukasi, banyak ibu hamil yang merasa berisiko cenderung memeriksakan dirinya (HIV testing) karena sadar akan kemungkinan risiko penularan ke bayi yang besar selama hamil, bersalin dan menyusui. Peningkatan pengetahuan tentang pencegahan dan penularan HIV/AIDS sangatlah penting, namun pola pendekatan untuk usaha peningkatan pengetahuan tersebut yang nantinya dapat dijadikan praktek dalam menurunkan angka kejadian HIV/AIDS adalah lebih penting. ${ }^{9}$

\section{KESIMPULAN DAN SARAN}

1. Mitos mengenai penularan HIV/AIDS melalui makanan masih tinggi pada aspek pengetahuan ibu hamil

2. Sikap negatif pada penderita HIV/AIDS ditunjukkan dengan tidak ingin membeli makanan yang dijual oleh penderita HIV/AIDS.

\section{DAFTAR PUSTAKA}

1. Cynthia C, 2010. Handbook of HIV and social work: principles, practice and populations. US John Wiley \& Sons Inc

2. Ditjen P2P Kementerian Kesehatan RI Laporan Situasi Perkembangan HIV AIDS \& PIMS Di Indonesia Januari-Maret 2017. 2017

3. UNAIDS.2017. Overview Indonesia. www.unaids.org/en/regionscountries/indo nesia

4. Kluwers, Awareness and Attitude of the general Public Towards HIV/AIDS in Coastal Karnataka. Indian J Community Med. 2010 Jan; 35(1):142-146

5. Rahman A (2009). Determinants of Knowledge and Awareness about AIDS: Urban -Rural Differentials in Bangladesh. The Internet Journal of Health. Vol. 9 No. 2

6. Asefa and Beyene: Awareness and Knowledge on timing of mother-to-childtransmission of HIV among antenatal care attending women in Southern Ethiopia: a cross sectional study. Reproductive Health . 2013 10:66 
7. Malaju and Alene : Determinant factors of pregnant mothers' knowledge on mother to child transmission of HIV and its prevention in Gondar town, North West Ethiopia. BMC Pregnancy and Childbirth 2012. $12: 73$

8. Boateng D, Kwapong GD, Baffour PA. Knowledge, perception about antiretroviral therapy (ART) and prevention of motherto-child-transmission (PMTCT) and adherence to ART among HIV positive women in The Ashanti Region, Ghana: a cross-sectional study. BMC Women'c Health 2013.13:2

9. Mamudu RA. Knowledge Attitude and practices of prevention of mother to child transmission of HIV (PMTCT) among women of child bearing age, in Karu Village, Abuja, Nigeria. 2014. Stellenbosch University. Available at http://scholar.sun.ac.za

Tabel 1. Karakteristik Responden

\begin{tabular}{|c|c|c|c|}
\hline No & Karakteristik & $\underline{\mathrm{n}}$ & $\%$ \\
\hline \multirow[t]{4}{*}{1} & Umur & & \\
\hline & - $\quad 16-20$ tahun & 5 & 5 \\
\hline & $-\quad 21-35$ & 75 & 75 \\
\hline & $-\quad>35$ Tahun & 20 & 20 \\
\hline \multirow[t]{4}{*}{2} & Pendidikan & & \\
\hline & - $\quad$ SD-SMP (9 tahun) & 24 & 24 \\
\hline & - $\quad$ SMA (12 Tahun) & 57 & 57 \\
\hline & - $\quad$ Sarjana/Diploma(>12 tahun) & 19 & 19 \\
\hline \multirow[t]{3}{*}{3} & Kehamilan & & \\
\hline & $-\quad 1-2$ & 44 & 44 \\
\hline & $-\quad>2$ & 56 & 56 \\
\hline
\end{tabular}


Tabel 2. Pengetahuan Ibu hamil Orang Dengan HIV/AIDS (ODHA)

\begin{tabular}{ll}
\hline No $\quad$ Variabel & ( \% Benar) \\
\hline $1 \quad$ Pengetahuan & 58 \\
a. Apakah setia pada 1 Pasangan dapat mengurangi risiko HIV? & 45 \\
b. Apakah HIV menular melalui gigitan nyamuk? & 31 \\
c. Apakah Menggunakan kondom saat seks mengurangi risiko HIV & 29 \\
d. Apakah HIV dapat menur jika berbagi makanan? & 74 \\
e. Apakah HIV ditularkan melalui kekuatan Gaib? & 60 \\
f. Apakah orang tampak sehat mungkin menderita HIV? & 75 \\
g. Apakah HIV menular dari ibu ke ke janin & 45 \\
$\quad$ Selama hamil & 65 \\
Rata-Rata & Selama persalinan
\end{tabular}

Tabel 3. Pengetahuan dan Sikap Ibu hamil Orang Dengan HIV/AIDS (ODHA)

\begin{tabular}{llc}
\hline No & Variabel & ( \% Benar) \\
\hline 2 & Sikap Terhadap Penderita HIV/AIDS & \\
& \\
a. Apakah anda akan membeli makanan dari penjual yang mengidap HIV/AIDS? & 9 \\
b. Jika salah satu keluargamu menderita HIV, akankah kamu merahasiakannya? & 58 \\
c. Jika salah satu keluargamu menderita HIV/AIDS, akankah kamu & 77 \\
& merawatnya? \\
d. Jika salah seorang guru menderita HIV/AIDS namun tidak tampak sakit, & 35 \\
& apakah menurutmu dia bias melanjutkan untuk mengajar disekolah ? \\
& Rata-Rata
\end{tabular}

